\title{
“LUVINA" O LAS MAROMAS DEL HOMBRE AQUEL QUE HABLABA
}

\author{
Leonardo Sancho Dobles
}

\begin{abstract}
RESUMEN
El artículo ofrece un acercamiento a uno de los posibles sentidos del relato "Luvina", del escritor mexicano Juan Rulfo, desde la perspectiva de análisis formal de textos literarios; para dicho análisis se toman en cuenta elementos como la estructura, el espacio, el tiempo y el plano semántico; el acercamiento al sentido del texto se enriquece con otros elementos intertextuales que permiten establecer una interpretación diferente del relato.
\end{abstract}

Palabras clave: narrador observador, narrador principal, tiempo, deícticos, desplazamiento semántico.

\begin{abstract}
The article presents an approach to one of the possible interpretations of the story "Luvina", written by Mexican author Juan Rulfo, from the perspective of formal analysis of literary pieces. For this analysis, elements such as structure, space, time and semantic plane are taken into account. The approach to the meaning of the text is further enriched by different intertextual elements that permit establishing a different interpretation of the story.
\end{abstract}

Key words: Third person, main narrator, time, deictic, semantic warp.

Vi de igual modo a Sísifo, el cual padecía duros trabajos empujando con entrambas manos una enorme piedra. Forcejeaba con los pies y las manos e iba conduciendo la piedra hacia la cumbre de un monte; pero cuando ya

le faltaba poco para doblarla, una fuerza poderosa derrocaba la insolente piedra, que caía rodando a la llanura.

Tornaba entonces a empujarla, haciendo fuerza, y el sudor le corría de los miembros y el polvo se levantaba sobre su cabeza.

Homero, La Odisea, rapsodia XI

Leonardo Sancho Dobles. Magíster Litterarum en Literatura Latinoamericana. Profesor asociado de la Escuela de Estudios Generales.

Correo electrónico: leo_sancho@hotmail.com 


\section{No hay ningún escritor que escriba todo lo que piensa}

Juan Rulfo puede ser considerado quizás el narrador latinoamericano más enigmático. Se le conoce por haber publicado únicamente un libro de cuentos titulado El llano en llamas (1953) y la novela Pedro Páramo (1955), aunque también publicó textos dispersos, escribió guiones cinematográficos y se dedicó a la fotografía. No obstante, la densidad de su novela y sus cuentos es tal que durante un poco más de cinco décadas le han valido la atención de la crítica y la historiografía literaria, lo cual ha favorecido que el canon lo establezca como uno de los pilares y de los narradores más importantes de la literatura en lengua española y universal.

En alguna oportunidad el propio escritor reconoció que, dentro de los subgéneros narrativos, prefería al cuento sobre la novela ya que según confesaba: "el cuento es un género realmente más importante que la novela, porque hay que concentrarse en unas cuantas páginas para decir muchas cosas, hay que sintetizar, hay que frenarse; en esto el cuentista se parece un poco al poeta, al buen poeta" (Rulfo 1997: 390). En ese momento el autor hacía referencia al trabajo de condensación que un relato lleva consigo, a diferencia de la novela; por otra parte, aludía también al oficio lírico que el cuentista debe llevar a cabo, ya que en un cuento debe establecerse, a la misma vez, un nivel de abstracción y de recreación.

Dentro de las categorías del género épico, el cuento representa el texto literario en el cual, por su trabajo de reducción y de síntesis, es mayor la cantidad de lo que se deja por decir, que lo que en efecto dice; en tanto género narrativo el cuento es el texto literario que más espacio abre para las elucubraciones y las interpretaciones, por el mismo margen que la condensación deja para ello. La idea anterior es aplicable a la totalidad de la obra narrativa publicada por Juan Rulfo, en la cual -quizás por su brevedad y densidad- se presenta ante el lector y el crítico literario un caudal infinito para los trabajos de exégesis o hermenéutica; a pesar de su brevedad, los textos de El llano en llamas y Pedro Páramo constituyen dos de los textos más emblemáticos de la narrativa latinoamericana de la segunda mitad del siglo XX y ofrecen un amplio espacio para las interpretaciones, el cual todavía -poco más de cincuenta años de haber sido entregados a los lectores- no se ha agotado.

Con respecto a las relaciones que se establecen entre los libros publicados por Juan Rulfo, la crítica coincide en que el relato "Luvina", perteneciente a la colección de cuentos El llano en llamas, es la antesala de las imágenes fantasmales, el ambiente infernal y las estructuras narrativas que el escritor va a utilizar más adelante en la novela Pedro Páramo; al respecto la crítica literaria plantea:

\footnotetext{
Reducido al papel de testigo, incapaz de ser actor o portador de la buena palabra del saber escolar, ha sido condenado a decir para siempre jamás una realidad que le ha confiscado toda ilusión. Como los viejos de Luvina, que no pueden emigrar y dejar sus muertos, él no puede abandonar el recuerdo del no-tiempo de Luvina; donde los muertos parecen enterrar a los vivos, donde los lugares de unos y otros se confunden extrañamente. El cuento esboza claramente el proyecto literario de Pedro Páramo (Olivier 1997: 736).
}

Por otra parte, también los trabajos de exégesis coinciden en que en el texto "Luvina" se evidencian una serie de problemas sociales y de críticas veladas al sistema educativo en las zonas rurales mexicanas particularmente al fracaso del proyecto de Lázaro Cárdenas y la Revolución Cristera -la cual también ocupa un lugar en la novela Pedro Páramo en la compleja figura del personaje del padre Rentería-.

Creo que esto se refleja en el cuento 'Luvina'. Relato famoso en el que se prefigura el tono fantasmal que habrá de imperar en Pedro Páramo, este cuento de Rulfo es, entre otras cosas, una crítica en contra de la estrategia educativa de Cárdenas, y acaso no más en contra de Cárdenas. 
La voz de la narración es la de un maestro nostálgico y desengañado, quien dialoga (así se lo puede entender) con un colega que se encuentra de paso para ir a cubrir un puesto de profesor en la alejada población. (...) La decepción es notable. La forma en la que se refiere a las ideas, como una plasta, ilustra el desprecio con que se asume la ideología dominante. No es, acaso, que la educación socialista fuera mala per se. El texto de Rulfo no pretende iniciar un debate a ese nivel. Lo que quiere es mostrar la ineficacia de esta educación ideológica, la imposibilidad de ajustarla a la realidad circundante. De hacerla funcionar, en una palabra (Escalante 1997: 670).

Probablemente, de los cuentos que conforman El llano en llamas el de "Luvina" es el más enigmático y el más misterioso. El relato evidencia un preámbulo de los diferentes aspectos que el propio Juan Rulfo va a desarrollar en su célebre novela Pedro Páramo; por otra parte, también el texto establece una crítica social y política.

Retomando las ideas anteriores y aprovechando -además- el caudal que la narrativa de Rulfo deja abierto para las interpretaciones, las páginas sucesivas proponen un acercamiento uno de los posibles sentidos de este cuento, desde el análisis formal del texto y de las posibles relaciones intertextuales que se pueden establecer con la mitología clásica.

En alguna oportunidad el escritor mexicano advirtió: "no hay ningún escritor que escriba todo lo que piensa, es muy difícil trasladar el pensamiento a la escritura, creo que nadie lo hace, nadie lo ha hecho, sino que simplemente [hay] muchísimas cosas que al ser desarrolladas se pierden" (Rulfo 1997: 390). Probablemente esas "cosas" a las que hacía alusión el autor en su momento no se traten simplemente de ideas que se le extraviaran a la hora de concebir el texto, ni tampoco de mensajes cifrados que han quedado dispersos en el relato y que están puestos ahí, intencionalmente, para que el lector perspicaz los descubra; se trata de un trabajo de interpretación y de aproximación a uno de los tantos sentidos que se puede derivar del juego entre los significantes y las significaciones. Por lo tanto -partiendo de esta premisa fijada por el mismo Rulfo- este trabajo establece un aporte para hallar aquellas "cosas" que supuestamente se han "perdido" al ser escritas y que hacen que hoy, la obra producida por él, tenga la misma, o quizás más, fuerza y vitalidad, que la de hace ya más de cincuenta años.

\section{Luego, dirigiéndose otra vez a la mesa, se sentó y dijo}

En primera instancia, el relato "Luvina" hace evidentes una serie de aspectos llamativos e interesantes en el nivel de la narración. En el texto se leen, o escuchan, las voces de dos diferentes narradores, el narrador que interviene de primero en el relato -para efectos de este trabajo se denominará también narrador principal- al cual la crítica clasifica como un narrador testigo desde el punto de vista de la primera persona -aunque la diferencia entre la categoría narrador testigo y protagonista sea muy tenue en este caso-, y el segundo narrador que participa de la acción narrativa, el narrador observador, cuya voz e intervenciones breves enmarcan la situación y la escena en las cuales se lleva a cabo el relato del narrador primero o el "hombre aquel que hablaba". Se trata de una situación enmarcada en una denominada "tienda", o lugar de paso, al pie de la loma y la cuesta de la Piedra Cruda por donde se llega hacia el pueblo denominado Luvina el cual ocupa el lugar de referente en el relato. En este texto, la presencia del narrador observador sirve de encuadre -en una acepción gráfica del término- del espacio para que emerja y fluya libremente la voz y el discurso del hombre aquel que hablaba.

El narrador observador interviene apenas en cinco breves oportunidades a lo largo del cuento y sus intervenciones se intercalan con los largos fragmentos del narrador principal. En 
las ocasiones en las que interviene la voz del segundo narrador, el observador hace énfasis en tres aspectos. En primer lugar se refiere a las acciones y a los movimientos del hombre que habla: se levanta, sale a silenciar a los niños que juegan a fuera de la tienda, se dirige hacia la mesa, se queda callado un rato, bebe su cerveza, mira a los comejenes que revolotean sobre la lámpara de petróleo y se queda dormido; en segundo lugar esta voz narrativa hace mención a los sonidos externos al espacio de la tienda y que interfieren también en el cuento -el sonido el río que pasa las aguas crecidas por las ramas de los camichines, los gritos de unos niños que se acercan o se alejan e invaden el espacio interno, el rumor del aire que mueve las hojas de los almendros-; finalmente, esta voz narrativa hace referencia al transcurrir del tiempo, particularmente con sonidos que hacen que se escuche el avance de la noche y a las estrellas que se perfilan a través de la puerta de la tienda. En este sentido es notable que este narrador haga énfasis en los sonidos exteriores que intervienen, y a la misma vez interfieren, con la voz narrativa del hombre aquel que hablaba, el narrador principal; esta voz narrativa es lo único que se puede escuchar en el espacio interno del relato, en el espacio que sirve de marco y, a la vez, de lugar de paso. Esto hace que se evidencie una diferencia entre los espacios exteriores e interiores y que en el cuento se manifieste una dicotomía entre el "adentro / afuera" -además de los ya observados por la crítica entre el "arriba / abajo" y el "aquí / allí"-, los gritos que se acercan y alejan, además del rumor del aire y el sonido del río que corresponden al espacio exterior y dentro del espacio interno emerge la voz del hombre aquel que hablaba. El ambiente en el cual se lleva a cabo la acción narrativa queda delimitada por la oposición "interna / externa" pues en la parte de afuera del espacio de la denominada tienda se escuchan diferentes sonidos mientras que adentro de la tienda lo que el lector escucha es solamente la voz de narrador principal; por lo tanto, la narración -interior- se opone a los sonidos exteriores y quien escucha -o lee- el relato lo hace interferido por los ruidos exteriores que invaden la narración y la fragmentan.

En cuanto al relato referido por el hombre aquel que hablaba, es llamativo el hecho de que su intervención -entrecortada cinco veces por el narrador observador como se anotaba anteriormente- se organice a manera de un diálogo con un interlocutor preciso y definido, quien al parecer lo escucha: "Pues sí, como le estaba diciendo...", "Me parece que usted me preguntó...", "Pero me permite primero que me tome su cerveza". Estos elementos retóricos utilizados en su discurso hacen que la narración aparente ser un diálogo, pero en ningún momento interviene el destinatario o un interlocutor determinado, lo cual hace que no haya reciprocidad ni diálogo entre quien habla y quien responde; por lo tanto esta narración se caracteriza más bien como un soliloquio o un monólogo. "Los monólogos interiores de los personajes no son «corrientes de conciencia», sino más bien relatos que parecen contarse a sí mismos, verdaderos destinatarios incluidos en el relato" (Olivier 1997: 732). Por otra parte, los cinco núcleos narrativos enunciados por el narrador principal no tienen una estructura coherente en cuanto al tiempo narrativo, la organización de las ideas es antojadiza y no tiene una secuencia lógica entre las secciones que la conforman; más bien el enunciado tiende a organizarse con la misma lógica de las evocaciones -como lo es en la mayoría del cuento- de los pensamientos o de los sueños, de forma fragmentaria también. Además, las intervenciones de este narrador incorporan en su interior el diálogo directo con otros personajes evocados en su recuerdo: el arriero, Agripina y los hombres y las mujeres de Luvina; este recurso hace que la estructura del cuento resulte aún más compleja y enigmática. 
La frase que da título a este apartado, pronunciada por el narrador segundo resulta bastante significativa, sugerente y, a la vez, ambigua; ejemplifica la situación narrativa de "Luvina". Podría pensarse, en primera instancia, que el hombre aquel que hablaba se dirija, si se tratara de una situación de movimiento y espacio, en dirección hacia la mesa; sin embargo, el verbo dirigir puede tener también el significado de elocución o de audiencia; por tales razones no queda claro hacia dónde o a quién se dirige esta voz narrativa con lo cual se inaugura, por parte del narrador observador, la ambigüedad del relato. Esa frase evidencia que entre el narrador de la experiencia en el pueblo de Luvina y su interlocutor no existe un nexo claro, es decir no se evidencia una precisión en el auditorio del discurso; por su parte, el narrador que encuadra este espacio lo que hace es apenas sugerirle al lector detalles, pues finalmente es el lector quien va a ocupar el lugar escucha o de supuesto interlocutor paciente en este texto. El lector del cuento "Luvina" viene a ocupar el lugar de quien escucha, precisamente el soliloquio del hombre aquel que hablaba, el lector se constituye en una suerte de interlocutor / lector. El lector está invitado a pasar adelante, a la tienda y la situación marco, y a escuchar la voz del hombre aquel que hablaba quien evoca el pasado, precisamente en un lugar de paso y ambiguo en donde emerge el relato.

\section{Afuera seguía oyéndose cómo avanzaba la noche}

En cuanto a la categoría espacial establecida en el cuento "Luvina", el relato sugiere algunas oposiciones entre diferentes lugares mencionados a través del narrador principal; además, por su parte la crítica canónica ha ubicado las oposiciones espaciales más importantes como las demarcadas por deícticos o los adverbios de lugar "aquí / allá", "arriba / abajo", "antes / ahora"

\footnotetext{
Sin embargo, las oposiciones más importantes y más exploradas en la escritura de Rulfo son las de algunos deícticos, esos términos cuyo significado depende totalmente del momento de la enunciación; Rulfo da especial preferencia a: tú-yo, aquí-allá, antes-ahora y arriba-abajo. Los argumentos principales de la mayor parte de los textos se relacionan directamente con alguna de las oposiciones de estos deícticos. Por ejemplo el cuento «Luvina» se basa en la oposición aquí-allá, combinada con yo allá-yo acá y usted allá-usted acá (Mansur 1997: 765).
}

El espacio particular en el que se lleva a cabo la narración enmarca una serie de oposiciones con respecto a la ubicación de otros los espacios narrativos evidenciados en el relato. Como primer aspecto, se hace notar una oposición entre los espacios definidos por los adverbios aquí y allí -entre otras oposiciones delimitadas, a su vez también, por aspectos temporales "antes / ahora"-. El deíctico aquí pertenece al espacio del narrador observador, en cuanto al marco de referencia espacial que establece en sus breves intervenciones, y el otro deíctico allí se refiere al espacio que le corresponde al discurso del narrador principal: la evocación el pueblo de Luvina.

En tres oportunidades, el hombre aquel que hablaba le dice a su supuesto interlocutor -el cual, se supone, se dirige hacia el pueblo de Luvina-: "Usted que va para allá se dará cuenta”. Mientras se lleva a cabo este encuentro o este discurso, los personajes se reúnen en un espacio delimitado y definido, por parte del narrador observador, como una tienda tal cual se ha observado en las líneas precedentes. Ambas voces narrativas se encuentran en un lugar específico en cuanto a las referencias de espacio por el deíctico aquí. Sin embargo, lo 
más recurrente en el cuento son las referencias al espacio evocado de Luvina, en donde a nivel verbal aflora una proliferación de deícticos, los adverbios de lugar allí: "El aire que allí sopla la revuelve, pero no se la lleva nunca"; o el otro adverbio espacial: "Allá viví. Allá dejé la vida..."

Otra de las oposiciones que involucran las referencias espaciales, aunque se mencione desde el principio del relato no es tan evidente como el contraste anterior, es la que concierne los espacios "arriba / abajo". El cuento inicia haciendo referencia a la altura en la cual se encuentra ubicado el pueblo de Luvina, de manera muy precisa el relato se abre con la alusión al espacio y a la altura: "De los cerros más altos del sur, el de Luvina es el más alto y el más pedregoso". Con esta primera referencia, se puede agregar que existe una correlación entre las oposiciones "aquí / allî" y "arriba / abajo", ya que en el lugar en el cual discurre el discurso del narrador principal es precisamente una tienda al pie de los cerros altos del sur, se trata de un lugar ubicado espacialmente abajo, mientras que el discurso evocado se ubica en la parte superior, en el cerro más alto de los cerros altos del sur. Por otra parte, el lugar representado por la cuesta de la Piedra Cruda desempeña un papel importante porque es la vía que comunica los dos espacios y ambientes: el ahora y el evocado, el arriba y el abajo y, finalmente, el aquí y el allá; esta cuesta viene a servir de puente entre los dos espacios tal y cual lo plantea el narrador principal cuando se refiere a los espacios que sirven de nexo: "Dicen los de Luvina que de aquellas barrancas suben los sueños, pero yo lo único que vi subir fue el viento, en tremolina, como si allá abajo lo tuvieran encañonado en tubos de carrizo."

En un plano semántico, el espacio del pueblo de Luvina se caracteriza como un espacio intermedio entre la tierra y el cielo, un lugar de paso también, en el que se vive en un tiempo sin principio ni fin, como lo define la propia voz narrativa: "pero aquello es el purgatorio". Independientemente de las implicaciones que pueda tener el concepto purgatorio, en tanto una metáfora, de la culpa y la pena en el cuento -metáfora observada por la crítica como una constante en la producción narrativa de Rulfo-, la mención al espacio del purgatorio hace referencia a un espacio intermedio entre la tierra y el cielo de acuerdo con ciertas concepciones metafísicas "Más arriba que la tierra y más abajo que el cielo, «aquello es el purgatorio», dice quien ya estuvo allí, en el lugar donde «viven» los muertos, según reconocen sus habitantes." (San Martín 2006: 1). Esta idea del lugar intermedio entre otros dos espacios se refuerza con el argumento que presentan los hombres del pueblo "Malo cuando deja de hacer aire. Cuando eso sucede, el sol se arrima mucho a Luvina y nos chupa la sangre y la poca agua que tenemos en el pellejo. El aire hace que el sol se esté arriba. Así es mejor". El viento en tanto categoría también del aire, de acuerdo con la asociación que establece el mismo narrador principal, se trata de un elemento propio e inherente al espacio del pueblo; el "viento = aire" viene a significar ese otro elemento intermedio entre la tierra y el sol, a lo cual se refieren los personajes habitantes de Luvina.

En cuanto al tiempo de la narración y las demarcaciones espaciales, se puede observar que el discurso de la voz narrativa principal se lleva a cabo en el tiempo presente de la narración mientras que lo narrado ocurre en el tiempo de lo evocado, el antes, con lo cual se puede evidenciar otra de las oposiciones: "ahora / antes": "Resulta fácil ver las cosas desde aquí, meramente traídas por el recuerdo, donde no tienen parecido ninguno.” Además, a lo largo del relato no se evidencian distinciones entre el tiempo y el espacio, con lo cual se puede observar como parte de la estructura narrativa del texto que el "allá-antes" y el "aquí-ahora" corresponden dos unidades narrativas y dos narradores diferentes que a su vez pertenecen a una delimitación "temporal-espacial". 
Por otra parte, la referencia al tiempo en esta serie de oposiciones y contrastes se agudiza todavía más cuando el narrador principal plantea que el tiempo en Luvina es eterno: "Perdí la noción del tiempo desde que las fiebres me lo enrevesaron; pero debió haber sido una eternidad... Y es que allá el tiempo es muy largo". Esta idea anterior permite sugerir que en el relato se manifiesta otra oposición más entre los espacios y los tiempos, el tiempo del acá lineal y el tiempo allá eterno; el que corresponde al tiempo presente y al espacio de la tienda: el aquí-ahora-tiempo lineal; y el que corresponde al espacio y tiempo evocados en Luvina: el allá-antes-tiempo eterno.

Aparte de estas oposiciones, algunas ya definidas por la crítica como se apuntaba al inicio de este apartado, en el cuento se evidencia todavía una oposición más y es una que también tiene que ver con el espacio de la narración. Se trata de una diferencia que se demarca en el propio recinto de la tienda y tiene que ver con el exterior y el interior del lugar en el cual se lleva a cabo la supuesta conversación, es decir, el soliloquio del hombre que narra. Esta oposición la define claramente el narrador observador al utilizar el deíctico afuera en su afán por demarcar, enmarcar y encuadrar la narración; esto se evidencia sobre todo cuando este narrador hace referencia a los sonidos que se escuchan en el espacio exterior a la tienda; en sus intervenciones este narrador hace referencia específica a los sonidos que se desarrollan afuera de la tienda y que en ocasiones invaden el espacio del relato y del discurso y hacen que el hombre aquel que hablaba deba interrumpir su narración y se vea obligado a silenciarlos porque le impiden proseguir, lo distraen en su soliloquio. En la primera vez que interviene el narrador observador señala que el narrador principal se queda callado y mira hacia fuera, inmediatamente menciona los sonidos externos: "Hasta ellos llegaban el sonido del río (...) el rumor del aire (...) y los gritos de los niños..." En las otras oportunidades en las cuales el narrador observador se apropia de la palabra va a hacer nuevamente referencia los mismos sonidos ya mencionados: los gritos de los niños, el sonido del río y el rumor del aire; pero, además, agrega el particular sonido del avance de la noche que ocurre afuera de la tienda: "Afuera seguía oyéndose cómo avanzaba la noche". Resulta significativo el hecho de que en el exterior del espacio los gritos de los niños sean los que ingresan adentro del espacio interno de la narración y que el narrador principal deba silenciarlos, los gritos de los niños invaden el espacio, interrumpen: "Los gritos de los niños se acercaron hasta meterse dentro de la tienda"; pero también se alejan: "El griterío ya muy lejano de los niños"; en ningún otro momento en el relato se hace referencia a los sonidos que ocurren en el espacio interior de la tienda. Es más como referencia al espacio interno, en ningún momento se hace alusión al deíctico adentro, ni a los sonidos que se pueden contrastar con los externos; lo que se escucha con toda nitidez es la voz del hombre aquel que hablaba con la cual se oponen y contrastan los sonidos externos que a veces interfieren con el relato. Esta oposición "adentro / afuera", que se suma a las dicotomías anteriores, intensifica el sentido de la narración del cuento, al sugerir que afuera se escuchan los sonidos ya mencionados -el sonido del río, el rumor del aire, los gritos o el griterío de los niños y el avance de la noche- mientras que adentro lo único que se escucha es la voz del narrador principal, su supuesta conversación, su soliloquio.

En cuanto a la utilización de espacios en el cuento "Luvina" el relato evidencia un complejo juego de oposiciones y contrastes en los que intervienen elementos que van más allá de las referencias espaciales simples, pues para crear mayor énfasis en el discurso del narrador personaje se recurre a aspectos que intensifican el sentido y el espacio de la narración a la misma vez que agudizan la ambigüedad del texto. 


\title{
4. Por el pequeño cielo de la puerta se asomaban las estrellas
}

En su discurso, el narrador principal establece una argumentación fragmentaria entretejida por medio de una larga serie de evocaciones que evidencian, a su vez, un complejo juego de desplazamientos semánticos. Lo anterior trae como consecuencia que a nivel verbal en el texto de Rulfo se manifieste una generación de metáforas como pocas veces se observa el género narrativo pues el cuento posee un trabajo de figuración, por medio de la lengua misma, en el que proliferan las imágenes literarias y comparaciones a manera de símiles, o similitudes, y también las comparaciones y desplazamientos semánticos velados, por medio de la figura de la metáfora.

\begin{abstract}
Destinatario de su relato, hechizado por el sentido de sus propias frases, el personaje secreta obstinadamente un decir cuya estética busca la expresión más intensa para acosar al sentido perdido, multiplicando comparaciones y metáforas. Así el recuerdo figurado se transfigura y se hunde en la ficción en que se convierte todo el recuerdo contado; innumerables veces, probablemente (Olivier 1997: 737).
\end{abstract}

Durante sus cinco intervenciones, la voz narrativa que evoca el lugar de Luvina recurre a una larga serie de juegos metafóricos para tratar hacer más comprensible en otros niveles su relato; el narrador más importante del texto se esmera para que su discurso sea inteligible en otras dimensiones, más allá del entendimiento o la razón, por lo cual debe recurrir a metáforas sensoriales para producir en el interlocutor/ lector sensaciones en lugar de significados; lo anterior se debe a que en el relato las metáforas y los símiles sensoriales velan el sentido unívoco y referencial del texto y desplazan los significados hacia otras nuevas y diferentes dimensiones de sentido.

En cuanto a las figuras literarias, en el relato hay un total de treinta comparaciones o símiles y veintidós metáforas propiamente dichas. Se trata de un texto narrativo en el cual la proliferación de figuras literarias es tan abundante como ocurre en el género lírico. Esta emergencia del discurso figurado, por parte del narrador principal en sus intervenciones, se contrapone a la brevedad y precisión narrativas correspondientes al segundo narrador.

Para llevar a cabo una evocación de un espacio caracterizado como triste, lúgubre y fantasmal el narrador personaje debe recurrir a un encadenamiento de comparaciones para acercar, por medio de su propio discurso, el "allá-pasado-Luvina" hacia el "acá-presentetienda"; por ejemplo dentro del encadenamiento de imágenes, la descripción del cerro y del pueblo de Luvina se define como el caserío blanco que corona los cerros del sur "como si fuera una corona de muerto"; el propio pueblo se caracteriza como "el lugar donde anida la tristeza" y, para referirse a las acciones que ocurren en ese lugar, la voz narrativa necesariamente lleva a cabo traslaciones del sentido para evidenciar la supremacía de los aspectos sensoriales ante los intelectuales o racionales: "se oye un murmullo en todo el pueblo cuando regresan y uno como gruñido cuando se van" con lo cual en el plano discursivo se privilegia el aspecto sensorial ante el sentido propio del relato.

En tanto recursos retóricos metafóricos propiamente dichos en el plano de la lengua, los símiles establecen relaciones entre dos términos, dos conceptos o dos realidades y estas relaciones se manifiestan mediante semejanzas, afinidades o analogías que existen entre ellos; es decir, se trata de un recurso estilístico que lleva a cabo una equivalencia entre las cualidades de las ideas o los conceptos que se comparan. Es llamativo el hecho en el cual, dentro del encadenamiento de comparaciones en el discurso del texto "Luvina", de los treinta símiles identificables en el relato solamente nueve se construyen y estructuran con el morfema 
nexivo como mientras que los restantes símiles utilizan el enunciado comparativo como si. Estos últimos símiles establecen sentidos de semejanza entre dos situaciones o dos acciones y proponen que estas situaciones se llevan a cabo de modo o de manera parecida; esta comparación pertenece al campo gramatical de los adverbios ya que indican una semejanza o similitud entre dos verbos o acciones propiamente dichas.

En cuanto a los aspectos sensoriales que desplazan los significados posibles en la narración, en el relato se puede observar que en el caso particular de los símiles que no se construyen con el enunciado como si, sino con el nexo comparativo del adverbio como, estos símiles se refieren exclusivamente a elementos sensoriales: vista, oído, tacto y gusto y, dentro de este grupo, es evidente que predominan los símiles que hacen referencia al sentido del tacto y particularmente al sentido del oído.

\section{Cuadro 1}

\begin{tabular}{|c|c|c|c|}
\hline Visuales & Gustativos & Táctiles & Auditivos \\
\hline 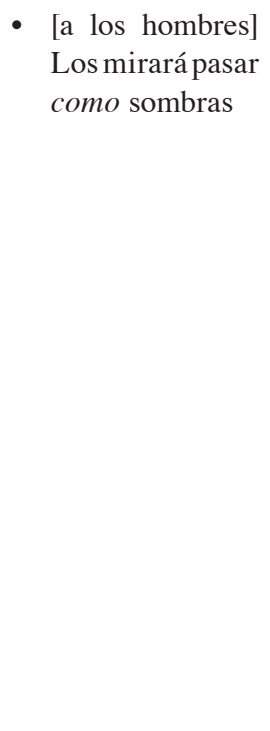 & $\begin{array}{l}\text { - [la cerveza tibia] agarra } \\
\text { un sabor como a mea- } \\
\text { dos de burro. }\end{array}$ & $\begin{array}{l}\text { - tanto que la tierra } \\
\text { además de estar reseca } \\
\text { y achicada como cuero } \\
\text { viejo } \\
\text { - [pasojos de agua] que } \\
\text { no son sino terrones } \\
\text { endurecidos como } \\
\text { piedras filosas } \\
\text { - [la tristeza] es } \\
\text { oprimente como una } \\
\text { gran cataplasma sobre } \\
\text { la viva carne del } \\
\text { corazón }\end{array}$ & 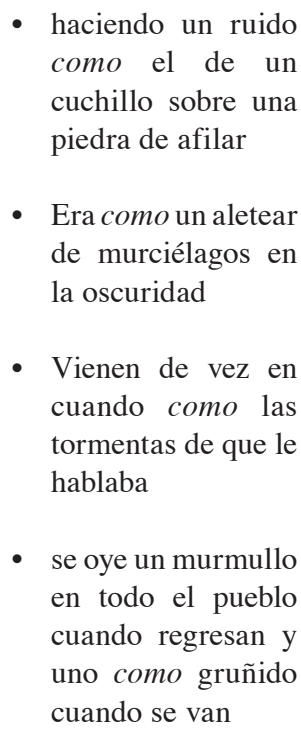 \\
\hline
\end{tabular}

Como se puede observar en el Cuadro 1, en el nivel táctil las sensaciones que se hacen evidentes para el interlocutor/ lector del cuento son de dureza, opresión y agresividad por el contacto con las superficies filosas o ásperas; mientras que en el nivel auditivo predominan las sensaciones particularmente de ruidos, murmullos y también de sonidos producidos por el aletear de murciélagos, los truenos y los cuchillos que se afilan sobre piedras; en ninguno de los dos sentidos se enuncian símiles de carácter positivo, por el contrario, todos aluden a imágenes oscuras, sonoras y agresivas. 
Con respecto a la otra serie de símiles, los que se construyen con el enunciado comparativo como si, es posible observar que establecen un vínculo entre dos situaciones y dos modos verbales; se trata de situación real, presente, tangible y literal que se lleva a un plano comparativo con otra situación evocada por medio del discurso, en un modo del verbo que a su vez resulta irreal en el plano de la narración. En cuanto a los modos verbales utilizados en este encadenamiento metafórico, llama la atención que la primera acción que antecede al nexo como si va enunciada en tiempos verbales del modo de indicativo, mientras que la segunda acción enunciada utiliza el tiempo pretérito pluscuamperfecto del modo subjuntivo. En este sentido es interesante observar en un plano eminentemente gramatical que los tiempos del modo indicativo pertenecen a la realidad o a la situación presente, mientras que los del modo subjuntivo corresponden a la situación evocada o irreal: "Se planta en Luvina prendiéndose de las cosas como si las mordiera"; la voz narrativa compara un momento preciso con otro que pertenece a otro modo de enunciar y se establece una similitud entre ambos con tal de dar a conocer un sentido diferente: "se oyó el aletear más fuerte, como si la parvada de murciélagos se hubiera espantado". Al enunciarse en tiempo pretérito pluscuamperfecto la acción evocada ha sido concluida y es anterior a otra acción pasada; además sintácticamente entre las dos situaciones comparadas se da una dependencia ya que la segunda acción está subordinada a la primera.

Entre las situaciones evocadas, el narrador insiste en hacer alusión a determinados momentos del relato y compararlos por medio del verbo atributivo estar para hacer énfasis en las descripciones de rasgos y características que definen al espacio "aquellos cerros apagados como si estuvieran muertos" o describen alguno de los elementos que conforman el espacio "de modo que la tierra por allí es blanca y brillante como si estuviera rociada siempre por el rocío del amanecer". Por otra parte, mediante otro verbo atributivo, el verbo ser, el narrador principal describe las acciones que ocurren en ese espacio de Luvina: "Luego, como si fueran sombras, echaron a caminar calle abajo"; este narrador recurrentemente hace referencia a las imágenes sensoriales y fantasmales en la construcción de estas comparaciones "amarradas con alambres que rechinaban a cada sacudida del viento como si fuera un rechinar de dientes" lo cual produce una imagen evocada mediante una sensación precisa y un sentido cada vez más difuso, oculto tras el símil.

Entre otras muchas que aparecen en el texto, las comparaciones desplazan semánticamente acciones que tienen que ver con el mundo descrito en el relato, se establece un juego de traslación del sentido entre diferentes acciones y situaciones que hacen alusión a la violencia, a los sonidos estruendosos, al estado de ánimo de los habitantes de Luvina y, por último, a la noción de tiempo. Nuevamente la voz narrativa del hombre aquel que hablaba evoca una serie de sensaciones enunciándolas, mediante un modo subjuntivo, y comparándola con otra acción más cercana al tiempo de la enunciación y tangibles desde el punto de vista del modo verbal. 
Cuadro 2

\begin{tabular}{|c|c|}
\hline Símil & Desplazamiento semántico \\
\hline Se planta en Luvina prendiéndose de las cosas como si las mordiera & plantarse / morder \\
\hline $\begin{array}{l}\text { hasta sentirlo bullir dentro de uno como si se pusiera a remover } \\
\qquad \text { los goznes de nuestros mismos huesos. }\end{array}$ & $\begin{array}{l}\text { sentirlo bullir dentro de uno } \\
\text { / remover los goznes de los } \\
\text { propios huesos }\end{array}$ \\
\hline $\begin{array}{l}\text { rebotando y pegando de truenos igual que si se quebraran en el } \\
\text { filo de las barrancas }\end{array}$ & $\begin{array}{l}\text { rebotar y pegar de truenos } \\
\text { / quebrarse en el filo de las } \\
\text { barrancas }\end{array}$ \\
\hline $\begin{array}{l}\text { Donde no se conoce la sonrisa, como si a toda la gente le hubieran } \\
\text { entablado la cara }\end{array}$ & $\begin{array}{l}\text { no se conoce la sonrisa / le } \\
\text { entablaron la cara }\end{array}$ \\
\hline $\begin{array}{l}\text { entonces todo se queda quieto, sin tiempo, como si se viviera } \\
\text { siempre en una eternidad }\end{array}$ & $\begin{array}{l}\text { quedarse quieto / vivir en la } \\
\text { eternidad }\end{array}$ \\
\hline
\end{tabular}

Como se puede observar, entre algunos de los símiles enunciados a lo largo del relato, en el Cuadro 2 se evidencia la idea que el narrador principal quiere dejar clara, precisamente en el segundo elemento de la comparación, se trata de sentidos que enfatizan el ambiente evocado como lúgubre, siniestro y fantasmal; por otra parte, también la voz narrativa establece una noción temporal diferente a la del tiempo lineal y cronológico.

En cuanto a otras figuras retóricas que tienen que ver también con las traslaciones de sentidos, en el cuento "Luvina" hay una presencia notable de las metáforas propiamente dichas. En particular se trata de juegos del sentido que se refieren, en algunos momentos, a las descripciones del ambiente tanto físicas "todo el horizonte está desteñido" o emocionales "es el lugar donde anida la tristeza". Estas descripciones también hacen referencia a la naturaleza, como es el caso de la vegetación cuando la voz narrativa se refiere a las dulcamaras y las describe como: "esas plantitas tristes que apenas pueden vivir untadas a la tierra, agarradas con todas sus manos al despeñadero de los montes"; también se da el caso de los fenómenos atmosféricos "el rocío se cuaja en el cielo", o bien, cuando la voz narrativa se refiere a las tormentas "que azotan la tierra y la desgarran". Sin embargo la utilización de metáforas que hacen referencia a lo vegetal y a los fenómenos naturales trasciende el sentido de la propia naturaleza y se llevan al plano de la naturaleza humana como es el caso cuando el narrador describe el retorno de los hombres a Luvina: "Dejan el costal de bastimento y plantan otro hijo en el vientre de sus mujeres...”, en este caso hace un desplazamiento semántico con el verbo plantar al darle un sentido que tiende hacia lo fisiológico y lo natural-vegetal en lugar de evidenciar los sentimientos en este tipo de relaciones entre hombres y mujeres, es más, con la metáfora anterior el narrador principal hace ver que los vínculos entre los hombres y mujeres de Luvina se dan solamente por razones eminentemente fisiológicas. 
Entre este conjunto de metáforas, también es llamativo el hecho de que el narrador personaje enfatice en las descripciones metafóricas alrededor de la figura del viento y el aire en el pueblo, pues lo menciona en sentido figurado en repetidas oportunidades. A lo largo de su narración hace referencia a las acciones nefastas del viento ya que "se planta en Luvina" y más adelante "dejando los paredones lisos, descobijados". Por otra parte, la voz narrativa debe recurrir a las metáforas para privilegiar los aspectos auditivos con respecto al sonido del viento: "uno lo oye (...) rascando (...) escarbando con su pala picuda" y más adelante en la narración dice que "lo estuvimos oyendo pasar por encima de nosotros, con sus largos aullidos; lo estuvimos oyendo entrar y salir por los huecos socavones de las puertas; golpeando con sus manos de aire las cruces del vía crucis..."

Resulta significativo, por otra parte, que la figura del viento a lo largo del relato aparece tanto al inicio y al cierre del discurso del hombre aquel que hablaba; al principio de su intervención, cuando comienza a describir los cerros del sur, este narrador plantea: "Dicen los de Luvina que de aquella barranca suben los sueños; pero yo lo único que vi subir fue el viento en tremolina como si allá abajo lo tuvieran encañonado en tubos de carrizo" y hacia el final de su intervención, cuando menciona las razones por las cuales sale del pueblo y que también discute con los hombres de Luvina para exhortarlos a salir de ahí dice: “¿No oyen ese viento? -les acabé por decir-. El acabará con ustedes". Significativamente el viento ocupa un lugar privilegiado en la discurso del hombre aquel que hablaba ya que este elemento abre y cierra su discurso y se le atribuyen cualidades de actor en el espacio del relato por medio de un significativo número de los desplazamientos semánticos. La figura del viento es la metáfora más recurrente a lo largo de la evocación de este narrador y en el texto cobra dimensiones diferentes y catastróficas que afectan no solamente el ambiente, en tanto espacio físico, también afectan el ambiente físico y emotivo de los personajes y de la voz narrativa principal.

Finalmente, en cuanto a figuras literarias, conviene mencionar también dentro del discurso del narrador principal se cierra con una hipérbole que le otorga a Luvina -tanto el espacio físico del pueblo como el cuento mismo- una dimensión aún más significativa en cuanto al carácter de los desplazamientos semánticos ya que se agudiza la idea oscura, triste y fantasmal del relato pues en ella el narrador personaje establece una descripción final en la que cierra de la siguiente manera:

San Juan Luvina. Me sonaba a nombre de cielo, aquel nombre. Pero aquello es el purgatorio. Un lugar moribundo en el que se han muerto hasta los perros y ya no hay ni quien le ladre al silencio; pues en cuanto uno se acostumbra al vendaval que allí sopla, no se oye sino el silencio que hay en todas las soledades. Y eso acaba con uno. Míreme a mí. Conmigo acabó.

Se trata, entonces, de una exageración que reúne varias imágenes en una sola serie: del sonido del nombre, la oposición entre cielo y el purgatorio; el estar moribundo y la muerte; del sonido recurrente y nocivo del viento y, finalmente, el silencio y la soledad. La voz narrativa principal cierra su discurso con una definición metafórica e hiperbólica en la que condensa un encadenamiento de ideas en una sola. Es más, mediante esta hipérbole, el interlocutor/ lector concluye su viaje evocado al espacio de Luvina gracias al discurso del hombre aquel que hablaba y la imagen que queda enunciada es principalmente la de la soledad y la de la muerte.

En el relato "Luvina" tanto los símiles, las metáforas e hipérboles y otros juegos semánticos funcionan a lo largo del texto como las imágenes verbales y discursivas que emergen y proliferan en el cuento como si fueran las estrellas que se asoman por el pequeño cielo de la 
puerta a las que hace referencia el narrador observador. El cuento se erige en una gran metáfora que a su vez comprende una eclosión desmedida de hipérboles, símiles, prosopopeyas y otras figuras retóricas las cuales le otorgan al relato una dimensión semántica muy particular gracias al desplazamiento mismo de los significados que la emergencia de imágenes provoca en el texto. El referente, el discurso evocado por el narrador principal, no puede ser enunciado de otra manera que no sea figuradamente, pues lo sensorial en este caso se aproxima más hacia lo indecible que a lo referencial y eso solamente se puede lograr y dar a conocer mediante el juego de las imágenes, las metáforas, los elementos retóricos del lenguaje y los desplazamientos semánticos. Como resultado de los desplazamientos semánticos el referente se puede hacer inteligible al auditorio, en el plano verbal los juegos de los significantes producen nuevas y diferentes significaciones.

\section{Me parece que usted me preguntó cuántos años estuve en Luvina, ¿verdad...?}

En su momento la obra narrativa de Juan Rulfo estableció una serie de aspectos diferentes e innovadores en cuanto a las estructuras de la narración en los subgéneros del cuento y la novela, como lo ha destacado la crítica y la historiografía desde entonces; en el caso particular del cuento "Luvina" y como se ha observado en los apartados precedentes, el relato ofrece una serie de juegos narrativos con respecto a los diferentes narradores en el relato y a los particulares espacios narrativos en los que se llevan a cabo las acciones. Por otra parte, como consecuencia de los espacios que se manejan a lo largo de la narración, también el cuento "Luvina" establece un complejo juego de contrastes temporales diferentes como se hacía notar en el apartado correspondiente al manejo espacial en el relato.

Con respecto al tiempo en la narrativa de Rulfo el crítico Carlos Blanco Aguinaga, al referirse en particular al cuento "Talpa" de la colección de El llano en llamas, establece una serie de elementos narrativos con respecto a la temporalidad, que bien pueden resultar afines también con el cuento "Luvina":

\footnotetext{
Una primera persona que, arrancado de esa escena ahora, empieza a hablarse a sí misma desde dentro, en forma de recuerdo, casi como el personaje de 'Luvina'. En ese recordar, ahora y antes, parecen ya ser el mismo instante (...) Más aún que en 'Luvina', el monólogo, con su repetición de frases e ideas, con su recoger al final de los párrafos lo dicho al principio, parece haber estancado para siempre los hechos exteriores a la meditación interior del personaje (Blanco 2003: 27).
}

En el relato confluyen diferentes tiempos narrativos que se organizan en torno al monólogo del narrador principal. El tiempo pretérito, correspondiente a la evocación del espacio de Luvina, en el cual se evidencia también a nivel de desplazamiento semántico mediante una superposición y predominio de los tiempos en el modo subjuntivo sobre los tiempos del modo indicativo para producir un mayor énfasis en cuanto al tiempo y al espacio que se pretenden traer al presente por medio de la evocación y el monólogo.

Por su parte, en cuanto al espacio y al tiempo correspondientes a la voz del narrador observador en la tienda, la narración se ubica en tiempo presente y lineal ya que a lo largo de sus intervenciones esta voz narrativa insiste en el avance de la noche en una secuencia progresiva: "Parecía ser aún temprano en la noche", "Afuera seguía oyéndose cómo avanzaba la noche". Como consecuencia del recurso de la mezcla temporal el lector/ interlocutor se encuentra en una encrucijada narrativa en la cual confluyen diferentes tiempos: 
El proceso de desintegración, en el punto inicial de sus relatos, está ya dado. No hay perspectivas, sólo un largo pretérito empotrado en el duro cascarón del presente, en ese momento en el que confluyen en un punto todas las circunstancias y caracteres de los hombres y del pueblo. Ese punto es la ruina y la ruina es lo único que carece de futuro (Moreno-Durán 2003: 358).

Ahora bien, como se ha observado en el relato en cuanto al tiempo gramatical confluyen el pretérito y el presente; a su vez, no solamente a nivel gramatical ambos morfemas temporales son diferentes, puesto que en las maneras de enunciar por parte de los dos narradores el tiempo correspondiente al narrador observador tiene un carácter lineal mientras que el tiempo correspondiente al discurso evocado por parte del narrador principal posee un definido carácter cíclico: "Los días comienzan y se acaban. Luego viene la noche. Solamente el día y la noche hasta el día de la muerte, que para ellos es una esperanza.” En el discurso del hombre aquel que hablaba, la noción del tiempo cíclico y recurrente está establecida a partir de una secuencia que va desde las horas hasta los días y los años. En cada uno de ellos se establece un ciclo particular; primeramente, la voz narrativa hace una relación entre las horas y los años para evidenciar que no existe diferencia entre ambos: "Y es que allá el tiempo es muy largo. Nadie lleva la cuenta de las horas ni a nadie le preocupa cómo van amontonándose los años".Por otra parte, con respecto a la noción y el ciclo del día este narrador apunta sobre la rutina de los hombres del lugar: "Estar sentado en el umbral de la puerta, mirando la salida y la puesta del sol, subiendo y bajando la cabeza...", donde describe en un mismo plano el tránsito del día y la rutina de los habitantes de Luvina. En cuanto a los ciclos anuales que ocurren en el espacio evocado el mismo narrador observa, por ejemplo, la llegada de las tormentas: "A mediados de año llegan unas cuantas tormentas que azotan la tierra y la desgarran (...) Pero después de diez o doce días se van y no regresan sino al año siguiente, y a veces se da el caso de que no regresan en varios años"; otro ciclo anual que también este narrador relaciona con el ciclo de las tormentas es el del regreso de los hombres a Luvina: "Vienen de vez en cuando como las tormentas de que le hablaba (...) y ya nadie vuelve a saber de ellos sino al año siguiente, y a veces nunca".

El tiempo cíclico en el relato está demarcado por la salida y la puesta del sol, llegada de las tormentas y de los hombres a Luvina. Los tiempos de las tormentas y del regreso de los hombres corresponden los ciclos de fertilidad, pero no siempre se cumplen porque puede ser que las tormentas no regresen sino dentro de varios años y los hombres no vuelvan nunca.

En el relato, el efecto cíclico no solamente pertenece a la categoría temporal pues también se manifiesta en el plano narrativo, en el orden secuencial particularmente cuando el narrador principal relata la llegada de él y su familia a pueblo de Luvina se puede observar la utilización del ciclo de apertura y cierre para enfatizar este elemento a lo largo de la narración pues no pertenece al plano semántico exclusivamente sino que se lleva al plano del orden narrativo. En el fragmento o la unidad narrativa en el que el narrador principal se refiere al primer día en el espacio de Luvina, la secuencia narrativa inicia y termina con la misma frase, se trata del primer contacto con el espacio y el ambiente del pueblo. En la retórica de apertura primeramente el narrador dice: "Entonces yo le pregunté a mi mujer: - ¿En qué país estamos, Agripina? Y ella se alzó de hombros". Luego, el narrador utiliza la misma fórmula retórica hacia el final del día: “- ¿Qué país es este, Agripina? Y ella volvió a alzarse de hombros”. Esta reiteración en un momento de apertura y cierre establece un mayor énfasis en el aspecto cíclico del relato pues el ciclo no solo es un referente del texto sino que también lo representa en el plano narrativo. 
Además del tiempo cíclico y rutinario existe en este discurso evocado la noción de tiempo eterno, sin límites, sin principio ni fin. Como plantea el narrador personaje al manifestar su noción de tiempo mientras estuvo allá, en el espacio del pueblo de Luvina donde se vive una dimensión temporal sin límites, sin principio ni término, eterna: "Perdí la noción del tiempo desde que las fiebres me lo enrevesaron; pero debió haber sido una eternidad..."

La noción de tiempo cíclico se demarca todavía más cuando se le agrega la noción de eternidad, con lo cual la particularidad temporal narrada por el hombre aquel que hablaba se agudiza pues además de constituirse en un ciclo, a su vez, se trata de un ciclo eterno: “...y entonces todo se queda quieto, sin tiempo, como si se viviera siempre en la eternidad".

Al encadenamiento de diferencias entre los espacios y los narradores que se ha establecido hasta el momento, es necesario agregar esta nueva diferencia entre el tiempo lineal y el tiempo cíclico. El aquí espacio de la tienda, ahora y tiempo presente lineal, correspondiente al narrador observador, se contrapone con el espacio evocado de Luvina, el allá antes, tiempo pretérito cíclico y eterno perteneciente al hombre aquel que hablaba.

\section{Usted ha de pensar que le estoy dando vueltas a una misma idea y así es, sí señor...}

En su discurso, el hombre aquel que hablaba, también recurre a la idea del ciclo, es decir, la noción cíclica no solamente es parte de su contenido en tanto tema con respecto al tiempo en Luvina, sino que también pasa a ser parte de su estructura narrativa. Su largo monólogo es un ir y volver sobre ideas, que no están hiladas entre ellas, y resultan repetidas y recurrentes pero retornan siempre a lo mismo: la soledad, la tristeza, la imagen del desconsuelo, la atmósfera gris; el tópico de la soledad resulta ser conceptualmente la idea recurrente en el discurso del narrador principal. Como el tiempo en el espacio evocado de Luvina gira en círculos cíclicos, eternamente, el discurso del narrador principal se apropia de la noción cíclica de la narrativa y, como se trata de un ciclo, el inicio retorna al mismo punto de partida, el tópico recurrente. El ciclo que se reinicia y es eterno a la vez; se trata de un juego narrativo del eterno retorno que se manifiesta en dos planos en el relato, a nivel semántico y sintáctico.

El eterno retorno se trata de un tema muy explorado en la filosofía y también ocupa, en la cultura occidental, un lugar importante en la mitología grecolatina. El estudioso de la culturas y las religiones Mircea Elíade dedica un trabajo extenso al tema y plantea que el eterno retorno consiste en una forma de entender el ser y la naturaleza que no tiene relación con el tiempo lineal, irreversible, y el destino humano; la concepción del eterno retorno en un espacio metafísico implica el triunfo de la vida sobre la muerte, pues siempre devenir cíclico se está regresando al inicio; el principio y el fin se unen para recomenzar ad infinitum como la imagen de la serpiente que se muerde la cola.

Ese «eterno retorno» delata una ontología no contaminada por el tiempo y el devenir. Así como los griegos, en el mito del eterno retorno, buscaban satisfacer su sed metafísica de lo «óntico» y de lo estático (pues, desde el punto de vista de lo infinito, el devenir de las cosas que vuelven sin cesar en el mismo estado es por consiguiente implícitamente anulado y hasta puede afirmarse que «el mundo queda en su lugar»), del mismo modo el «primitivo», conferir al tiempo una dirección cíclica, anula su irreversibilidad. El pasado no es sino la prefiguración del futuro. Ningún acontecimiento es irreversible y ninguna transformación es definitiva (Elíade 1985: 86). 
Con respecto a este tema visto desde la perspectiva de la mitología griega, el personaje que más está vinculado con el eterno retorno es Sísifo; aunque otros personajes míticos también traían implícita esta idea, sobre todo cuando se trataba de un castigo, como

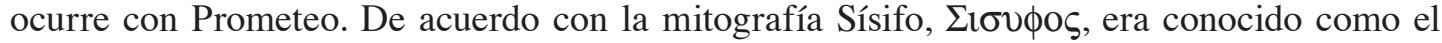
más astuto de los mortales y el menos escrupuloso. Las diferentes versiones en la mitografía que circulan alrededor de este personaje están colmadas de engaños, embustes y tretas; inclusive, algunas de sus artimañas están relacionadas con el hecho de que burló a la misma muerte y como castigo "Una versión dice que Zeus lo fulminó y lo precipitó en los Infiernos, condenándolo a empujar eternamente una enorme roca hasta lo alto de una pendiente. Apenas la roca llegaba hasta lo alto de la cumbre, volvía a caer, impelida por su propio peso, y Sísifo tenía que empezar de nuevo" (Grimal 1981: 485). El castigo de este personaje, por embustero y por haber burlado a la muerte consistió en el eterno retorno de subir una pesada piedra hasta la cima de una montaña y cuando finalmente lograba ascender, la fuerza y el peso - del destino- hacían que la pesada piedra descendiera y que, nuevamente, Sísifo volviera a emprender el ascenso, así sucesiva y eternamente.

Esta noción de eterno retorno - tanto como intertexto mítico como concepto metafísico-, del ciclo que se repite infinitamente, es también uno de los ejes que articulan el discurso del narrador principal de Luvina y que se complementa con la idea del tiempo narrativo cuando se evoca el espacio de Luvina. Por otra parte, el tema del eterno retorno incorpora, a su vez, la noción de castigo y de la culpa, un eje temático frecuente en toda la narrativa de Juan Rulfo.

Como se ha planteado en los apartados precedentes, el relato "Luvina" del escritor mexicano Juan Rulfo está organizado a partir de un complejo juego y articulación de oposiciones, comparaciones y dualidades. Estas dicotomías hacen que se evidencie a nivel de sentido una escisión entre dos partes que involucran tanto los espacios, como los discursos, los diferentes narradores y los tiempos en todas sus dimensiones: verbales y simbólicos.

\section{Cuadro 3}

\begin{tabular}{cc}
\hline Tienda & Luvina \\
\hline Narrador observador & Narrador principal \\
Discurso referencial & Discurso figurado \\
Aquí & Allí \\
Ahora & Antes \\
Abajo & Arriba \\
Presente & Pretérito \\
Modo indicativo & Modo subjuntivo \\
Tiempo exterior & Tiempo interior \\
Tiempo lineal & Tiempo cíclico y eterno \\
\hline
\end{tabular}

Esta dualidad evidenciada en el discurso general del cuento "Luvina" da margen para sugerir que tanto el emisor, o el narrador principal del relato, como su supuesto interlocutor -a quien se dirige- son una misma persona escindida en dos partes: la que habla y la que escucha; la que baja y la que sube; la que viene y la que va. El tiempo interior de lo narrado, 
correspondiente al espacio evocado del pueblo de Luvina, y tiempo exterior del entorno y el encuadre de la tienda pertenecen al mismo personaje escindido, al soliloquio del hombre aquel que hablaba.

La estructura narrativa del relato, el aparente diálogo para el interlocutor ausente termina siendo un monólogo fragmentado y permite pensar que se trata del mismo hombre a quien va dirigido. El personaje narrador está dividido en dos -quien habla y quien escuchapero es el mismo sujeto, el que viene llegando de Luvina y el que se dirige hacia allá; es más, en algún momento hacia el final del relato el narrador se apropia del lugar de su interlocutor, cual si fueran ambos una sola unidad que se encuentra escindida: "Fui a ese lugar con mis ilusiones cabales y volví viejo y acabado. Ya ahora usted va para allá... Está bien. Me parece recordar el principio. Me pongo en su lugar y pienso... Mire usted, cuando yo llegué por primera vez a Luvina...". Su pensamiento emerge en voz alta, a manera de discurso evocado y de recuerdos, eso es lo que ocurre desde el inicio del cuento y lleva al lector de la mano hasta el final del relato. El personaje escindido se encuentra en un lugar de tránsito, donde también circulan ruidos, gritos, voces y emerge el relato mismo de Luvina; eso permite sugerir que en ese espacio en el que transitan los discursos el hombre aquel que hablaba se encuentra dividido en dos. "Pero mire las maromas que da el mundo. Usted va para allá ahora, dentro de pocas horas. Tal vez ya se cumplieron quince años que me dijeron a mí lo mismo...". Las maromas en el cuento no son solamente físicas, como las de aquel hombre que estuvo compelido eternamente como un castigo a su falta a subir una piedra hasta la cima de una montaña, sino que también tienen que ver con las peripecias del narrador personaje para ir y venir en su soliloquio y envolver a su interlocutor/ lector del relato y del discurso. Las maromas del hombre aquel que hablaba, en el caso del cuento "Luvina" son también retóricas, textuales y figuradas. Se trata de trucos, giros, vueltas y cambios que se llevan a cabo en el plano del lenguaje.

Hacia el final del texto, este personaje que ha elaborado una serie de giros discursivos, trucos retóricos y maromas poéticas deja la palabra y hace silencio. Esta es la única manera de cerrar su ciclo y dejar que el discurso siga fluyendo, como el rumor del río. "El hombre que miraba a los comejenes se recostó sobre la mesa y se quedó dormido". El narrador principal, el hombre aquel que hablaba cede la palabra y pasa a ser el hombre que miraba a los comejenes, deja de ocupar el lugar de quien enuncia, se desprende del verbo y se desvanece por medio de la mirada en el sueño y en el silencio para dar paso a que su interlocutor -el que también es el lector- ocupe el lugar de la palabra e interprete el texto.

El inicio se vuelve a repetir, el narrador principal ocupa el lugar del otro, el silencio, nuevamente los papeles se intercambian y el tiempo cíclico vuelve a circular una vez más eternamente. Sísifo ha reiniciado una vez más su camino hacia Luvina.

\section{Notas}

1. Todas las referencias al texto "Luvina" pertenecen a la edición de Rulfo, Juan. 1997. Toda la obra, edición crítica a cargo de Claude Fell. Madrid: ALLCA XX. 


\section{Bibliografía}

Blanco Aguinaga, Carlos. 2003. "Realidad y estilo en Juan Rulfo". En: Campbell, Federico (comp.), 19-43.

Buxó, José Pascual. 1997. "Juan Rulfo: Los laberintos de la memoria”. En: Fell, Claude (ed.), 711-718.

Campbell, Federico (comp.). 2003. La ficción de la memoria. Juan Rulfo ante la crítica. México D.F.: Era/UNAM.

Elíade, Mircea. 1985. El mito del eterno retorno. $6^{\text {a }}$ edición. Madrid: Alianza Editorial.

Escalante, Evodio. 1997. “Texto histórico y texto social en la obra de Rulfo”. En: Fell, Claude (ed.), 663-684.

Franco, Jean. 1997. "Viaje al país de los muertos”. En: Fell, Claude (ed.), 865-876.

García, Nelly. 1998. Cien años de literaturas hispanoamericanas. San José: EUCR.

González Boixo, José Carlos. 1997. “Lectura temática de la obra de Juan Rulfo”. En: Fell, Claude (ed.), 651-662.

Grimal, Pierre. 1981. Diccionario de mitología griega y romana. Barcelona: Editorial Paidós.

Mansur, Mónica. 1997. “El discurso de la memoria”. En: Fell, Claude (ed.), 753-772.

Moreno-Durán, Rafael Alberto. 2003. “La sublimación y la expresión del mito”. En: Campbell, Federico (comp.), 354-363.

Olivier, Florence. 1997. "La seducción de los fantasmas en la obra de Juan Rulfo". En: Fell, Claude (ed.), 719-752.

Rulfo, Juan. 1997. Toda la obra; edición crítica a cargo de Claude Fell. Madrid: ALLCA XX.

San Martín, Daniel. "San Juan Luvina". http://www.ficciones.com.ar/Critica/rulfo.htm. Consulta: 27 de octubre de 2006.

Solano, Rónald. 1998. “QQué (nos) hace un cuento?”. En: García (comp). 76-84. 